\title{
Comparison of petal senescence in forced and unforced common lilac flowers during their postharvest life
}

\author{
Agata Jędrzejuk · Julia Rochala $\cdot$ Marta Dolega • \\ Aleksandra Lukaszewska
}

Received: 13 July 2012/Revised: 10 December 2012/ Accepted: 3 January 2013/Published online: 22 January 2013

(C) The Author(s) 2013. This article is published with open access at Springerlink.com

\begin{abstract}
Recently, the programmed cell death (PCD) is studied in the context of the postharvest longevity of cut flowers with the goal of slowing down the processes that ultimately lead to flower death, and to ensure a long display life of cut plant material. In this study, the phenomenon of PCD in petals of common lilac (Syringa vulgaris L.) was observed, aimed to compare degradation of petal cells in flowers blooming under natural conditions with those forced in November. For the early lilac forcing, a deep dormancy has to be broken by high temperatures $35-37{ }^{\circ} \mathrm{C}$ negatively affecting postharvest life of cut branches. The trials included as well the observation of the effect of two flower preservatives on the PCD in order to see if the prolongation of the lilac vase life was associated with a delay in the onset of the PCD symptoms. The vase life of cut lilacs was significantly increased by both preservatives. The first symptoms of PCD were evident in the flower bud stage. In petals from forced shrubs, the first symptoms of cell degradation were much more advanced than in lilacs blooming naturally in May. In forced flowers held in the preservatives, the degradative changes in cells occurred later than in those kept in water, but they were accelerated relative to a flower developmental stage.
\end{abstract}

Keywords Programmed cell death - Preservative · Postharvest life $\cdot$ Cut flowers

Communicated by U. Feller.

A. Jędrzejuk $(\varangle) \cdot$ J. Rochala $\cdot$ M. Dolega $\cdot$ A. Łukaszewska Department of Ornamental Plants, Faculty of Horticulture and Landscape Architecture, Warsaw University of Life Sciences-SGGW, Nowoursynowska 166, 02-787 Warsaw, Poland

e-mail: Agata.jedrzejuk@wp.pl; agata_jedrzejuk@sggw.pl

\section{Introduction}

Senescence is the culmination of development for plant organs, such as leaves, flowers and fruits. Its ultimate stage is called programmed cell death (PCD). PCD is an intrinsic part of the life cycle of all multicellular organisms, both animals and plants (Ellis and YuanJ 1991; Greenberg 1996; Pennell and Lamb 1997; Green 1998). PCD is critical for normal development, maintenance of tissue homeostasis, and the defense response (White 1996; Mittler et al. 1996). This default cell-suicide process can be initiated by a variety of stimuli, including developmental signals and environmental cues (Vaux and Korsmeyer 1999; Wertz and Hanley 1996). In flower petals, senescence can be triggered by pollination or wounding, and in some cases, it can be accelerated by a treatment with ethylene or abscisic acid (Rubinstein 2000). It is not clear how exactly the petal cells die. The main site of membrane and organelle degradation appears to be the vacuole (Winkenbach 1970; Matile and Winkenbach 1971; Phillips and Kende 1980; Smith et al. 1992). Petal cells in several genera, such as Ipomoea (Winkenbach 1970), Dianthus (Smith et al. 1992), Hemerocallis (Stead and van Doorn 1994), and Iris (van Doorn et al. 2003) show reduction in the number of small vacuoles, and an increase in vacuolar size. The ongoing increase in vacuole volume is usually accompanied by the loss of a considerable part of the cytoplasm and the disappearance of most organelles.

Owing to the detachment from the mother plant, cut flowers are usually under water stress. This shortens their longevity, both directly and indirectly via PCD. During the postharvest life, probably as a consequence of mechanical injury at harvest, xylem vessels at the basal stem parts usually become obstructed by microorganisms and tyloses, a common phenomenon; especially, frequent in woody cut 
flowers, such as common lilac (Jędrzejuk and Zakrzewski 2009). Tyloses are parenchymatic cell outgrowths that fill the vessels' lumen and impede water transport towards the flower/inflorescence. It has been recently confirmed (Rabiza-Swider and Skutnik 2010; Skolimowska et al. 2011) that arrest of the blockage formation in stem vessels prolongs lilac vase life.

Under the natural climatic conditions of Poland, common lilac opens its flowers in May. The flowering period is relatively short, as it is completed by the end of May. Overcoming periodicity and prolonging plant flowering beyond the natural period has always been a point of interest to scientists and growers (Dale et al. 1999). In common lilac, forcing is commonly used to produce flowers during 5-6 months per year. Forcing requires overcoming winter dormancy. The most effective temperatures required to break winter dormancy are between 0 and $5{ }^{\circ} \mathrm{C}$, for between 260 and $1,000 \mathrm{~h}$ (Wareing 1985; Borkowska 1987). Common lilac, especially the white flowering cultivar 'Mme Florent Stepman', is often produced for cut flowers as early as in November. November is too early to overcome dormancy naturally with low autumn/winter temperatures and the time is too short to cool shrubs effectively in a cold room. Hence, high temperatures in the range of $35-37{ }^{\circ} \mathrm{C}$ must be applied for the first 4-6 days of the forcing protocol in a greenhouse. These temperatures are close to the heat shock level and lead to degradation of generative structures, i.e. pollen grains and embryo sacs in the flowers (Jędrzejuk 2005; Jędrzejuk and Szlachetka 2005; Jędrzejuk and Łukaszewska 2008). After breaking of inflorescence bud, the temperatures are decreased to the range of $30^{\circ} \mathrm{C}$, during the inflorescence elongation phase- to $24-25^{\circ} \mathrm{C}$, during flower bud whitening phase- to $20^{\circ} \mathrm{C}$ and to $16{ }^{\circ} \mathrm{C}$ up to flowering phase. The November-produced flowering stems of common lilac have a shorter vase life than these blooming in months closer to the natural flowering period (Sytsema-Kalkman 1991; Skolimowska et al. 2011). In this study, the phenomenon of PCD in petals of common lilac was studied, comparing degradation of petal cells in flowers blooming under natural conditions with those forced in November. In addition, the effect of two flower preservatives on the PCD was observed to see if the extended lilac vase life was associated with a delay in the onset of the PCD symptoms.

\section{Materials and methods}

The flowering stems of common lilac 'Mme Florent Stepman' were collected in May from shrubs grown outdoors in the university didactic garden (controls), and in November from plants forced in a plastic tunnel at the horticultural enterprise of M. Łyczko in Grodzisk Mazowiecki (central Poland). The stems were harvested when one-third of the florets in racemes were open, they were immediately transferred to the laboratory, trimmed to $50 \mathrm{~cm}$ and placed in the standard preservative containing $200 \mathrm{mgdm}^{-3} 8 \mathrm{HQC}$ with $2 \%$ sucrose or in Chrysal Professional $^{\circledR}$ 2. The exact composition of the Chrysal Professional ${ }^{\circledR} 2$ is a trade secret, but it contains biocides and some nutrients to sustain respiration (Molenar 2009). It is recommended for cut flowers' traders and florists. The solutions were prepared in distilled water which also served as a control treatment. Water and solutions were not exchanged during the experiments, but their depletions were supplemented twice a day. There were ten shoots in each treatment, individually tagged and treated as separate replications. Experiments were conducted at a temperature of $18-20{ }^{\circ} \mathrm{C}$ and the 12 -h photoperiod, under luminescent light with a quantum irradiance of $25 \mu \mathrm{mol} \mathrm{m} \mathrm{m}^{-2} \mathrm{~s}^{-1}$. A relative air humidity was maintained at $70 \%$. The vase life was regarded as terminated if any of the following symptoms: wilting, drying and/or browning appeared on $30 \%$ of the florets.

Samples for microscopy were collected from both cut lilacs and from inflorescences on shrubs that bloomed naturally outdoors in May, and those forced in a greenhouse in November. Batches of extra stems for sampling were tagged on shrubs apart from those observed for longevity. Similarly, additional stems were cut and placed into water and the preservatives, concomitantly with those observed for vase life. Samples from stems on shrubs were collected at four phenological phases: flower bud, open flower, wilted flower, and desiccated flower; samples from cut stems were gathered in the stages of wilted and desiccated flower. Five florets from the lowermost whorls were collected from each of ten stems in each treatment for the flower stages described above. Collected samples were handled according to the Methods of Preparation for Electron Microscopy (Robinson et al. 1987). In brief, the material was fixed for $6 \mathrm{~h}$ in $5 \%$ glutaraldehyde and $4 \%$ formaldehyde in $0.1 \mathrm{M}$ sodium cacodylate buffer, $\mathrm{pH}$ 7.2-7.3 at $0.8 \mathrm{Atm}$ at room temperature, rinsed with the same buffer, postfixed in $2 \% \mathrm{OsO}_{4}$ in the $0.1 \mathrm{M}$ cacodylate buffer for $2 \mathrm{~h}$, and rinsed again with the same buffer. Fixed material was dehydrated in graded ethanol and acetone and embedded in a hard-grade epoxy resin (SERVA), similar to the former Epon 812. Semi-thin $(3 \mu \mathrm{m})$ sections were sectioned on a Jung RM2065 (Leica/Reichert-Jung) microtome, stained with methylene blue and azure B, dried at $70{ }^{\circ} \mathrm{C}$, and observed under bright field microscope (AX Provis, Olympus). Ultrathin sections were stained with $2 \%$ uranyl acetate and lead citrate according to Robinson et al. (1987), and observed under an electron microscope (JEM 100C, JEOL) in the Analytical Centre at Warsaw 
University of Life Sciences (WULS). The diameter of epidermis and mesophyll cells in petals of lilac were measured under the bright field microscope AX Provis, Olympus with Quick Photo Pro software. The diameter of epidermis and mesophyll cells was analysed by using analysis of variance (Anova 1) with Stagraphics 4.1 program. Means were compared using Duncan's multiple range test at $P=0.95$.

\section{Results}

Vase life

Inflorescences on the shrubs blooming in May lasted 22 days while those from shrubs forced in November lasted for 17 days (Table 1). Detached stems placed in water had a vase life of 5.1 and 2.4 days in May and November, respectively. The vase life of cut lilacs was significantly increased by the treatments: in November, 2.4 and 2.8 times by Chrysal Professional 2 and $8-\mathrm{HQC}+\mathrm{S}$, respectively, and in May, 2.3 and 2.0 times, respectively. There were no significant differences between these two solutions.

Measurement of epidermis and mesophyll cell diameter in the petals of lilac blooming in May and November

The results of measurements of cell diameter in the petals of common lilac showed that epidermis cells had similar diameter in the petals of plants blooming under natural conditions in May and those forced in November (19.0-19.2 $\mu \mathrm{m})$. The diameter of epidermis cells decreased at the stage of wilted flower to $17.2 \mu \mathrm{m}$ in November and $17.8 \mu \mathrm{m}$ in May (Table 2), but significant difference between the cell size in the petals of plants blooming in May and November was visible already at the stage of open flower (Table 2). At the stage of wilted and desiccated flower the diameter of epidermis cells did not differ significantly.

Table 1 Longevity of cut lilacs 'Mme Florent Stepman' as affected by blooming date and preservative

\begin{tabular}{|c|c|c|}
\hline Treatment/month & November & May \\
\hline Intact & $17.0 \mathrm{~d}^{*}$ & $22.0 \mathrm{e}$ \\
\hline Cut-distilled water & 2.4 a $(100 \%)$ & $5.1 \mathrm{~b}(100 \%)$ \\
\hline Cut-Chrysal Professional 2 & $5.8 \mathrm{~b}(242 \%)^{\mathrm{a}}$ & $11.6 \mathrm{c}(227 \%)^{\mathrm{a}}$ \\
\hline $\begin{array}{l}\text { Cut-200 mg dm } \\
8 \mathrm{HQC}+2 \% \text { sucrose }\end{array}$ & $6.8 \mathrm{~b}(283 \%)^{\mathrm{a}}$ & $10.0 \mathrm{c}(196 \%)^{\mathrm{a}}$ \\
\hline
\end{tabular}

* Means followed by the same letter do not differ significantly at $P=0.05$

a Percentage of the respective control
Table 2 Diameter of epidermis and mesophyll cell in the petals of common lilac on two blooming dates

\begin{tabular}{lllllll}
\hline & \multicolumn{2}{l}{ Epidermis } & & & Mesophyll & \\
\cline { 2 - 3 } \cline { 6 - 7 } & November & May & & November & May \\
\hline Flower bud & $19.0 \mathrm{a}$ & $19.2 \mathrm{a}$ & & $22.7 \mathrm{ab}$ & $24.1 \mathrm{a}$ \\
Open flower & $18.4 \mathrm{~b}$ & $19.2 \mathrm{a}$ & & $21.0 \mathrm{~b}$ & $23.9 \mathrm{a}$ \\
Wilted flower & $17.2 \mathrm{c}$ & $17.8 \mathrm{bc}$ & & $16.3 \mathrm{~d}$ & $18.4 \mathrm{c}$ \\
Dessicated flower & $17.2 \mathrm{c}$ & $17.2 \mathrm{c}$ & & $16.0 \mathrm{~d}$ & $18.1 \mathrm{c}$ \\
\hline
\end{tabular}

Means of a respective cell type followed by the same letter do not differ significantly at $p=0.05$

In petals of flowers blooming in May, the mesophyll cells were bigger than these in November and their diameter had $24.1 \mu \mathrm{m}$ at the stage of flower bud and $23.9 \mu \mathrm{m}$ at the stage of open flower (Table 2). On both flowering dates the diameter of mesophyll cells drastically decreased at the stage of wilted flower. The diameter of mesophyll cells decreased by $6.7 \mu \mathrm{m}$ in plants blooming in November and $6.0 \mu \mathrm{m}$ in plants blooming in May. During the postharvest life, both in May and November, the diameters of the petal cells from flowers on cut branches did not differ significantly from these on intact shoots.

PCD in petals of lilacs blooming naturally in May

Under the transmission electron microscopy of the mesophyll petal cells, signs of PCD were observed at the stage of flower bud. In these cells, the nuclei with well distinguishable nucleoli were still visible, but chromatin condensation was already underway (Fig. 1a). The nucleus was still surrounded by cytoplasm and its membrane remained unbroken. At this stage, the condensation of cytoplasm was already evident, and several small lytic vacuoles appeared. Only in a few cells, big lytic vacuoles completely filled the cell interior, leaving only traces of the peripheral cytoplasm (Fig. 1a). Other organelles, such as mitochondria, plastids, endoplasmic reticulum still preserved their shapes and looked undisrupted. The walls of the mesophyll cells remained undigested and so was the pectic middle layer between inner and outer cell walls.

The process of the programmed cell death progressed at the stage of open flower. Here, a large vacuole filled nearly the entire volume of the cell, pressing the remnants of the cytoplasm and other organelles against the cell walls (Fig. 1b). Mitochondria still preserved their shape (Fig. 1b), but digestion symptoms were visible, particularly in plastids and the endoplasmic reticulum (Fig. 1b). Nuclei lost their round shape and fragmented chromatin was apparent at the margins of the nuclei (data not shown). In some cell parts, wall bubbling was visible (Fig. 1b) and 

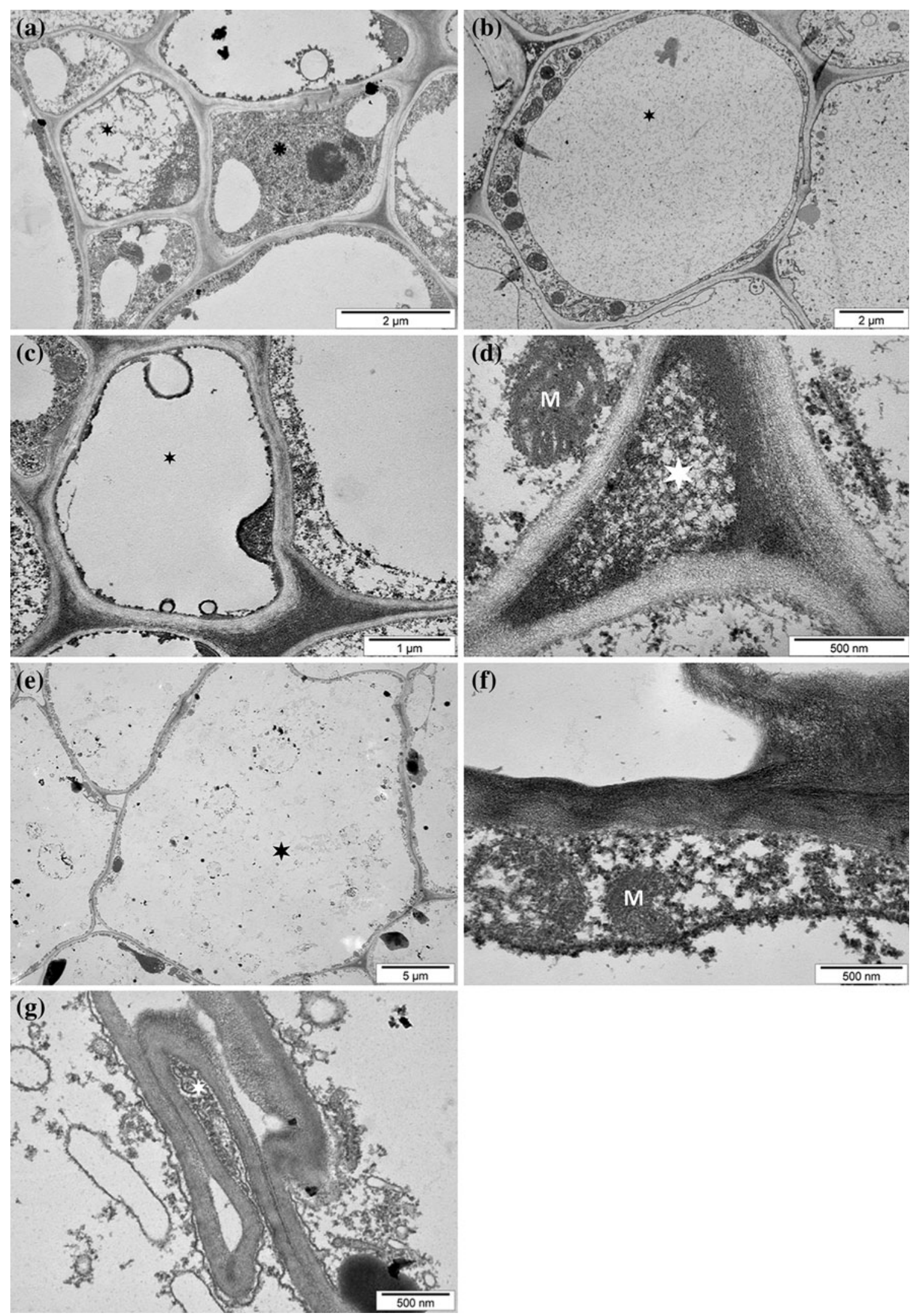
4 Fig. 1 a Degradation of cell organelles at the stage of flower bud. Control shrubs blooming in May. Eight pointed star nucleus, Six pointed star degrading cytoplasm. b Degradation of cell organelles at the stage of open flower. Control shrubs blooming in May. Six pointed star vacuole. c Degradation of cell organelles at the stage of wilted flower. Control shrubs blooming in May. Six pointed star vacuole. d Degradation of cell organelles at the stage of wilted flower. Control shrubs blooming in May. Six pointed star digesting intercellular substance, $M$ mitochondrion. e Degradation of cell organelles at the stage of dessicated flower. Control shrubs blooming in May. Six pointed star degrading cytoplasm $\mathbf{f}$. Degradation of cell organelles at the stage of dessicated flower. Control shrubs blooming in May. $M$ degrading mitochondria g. Degradation of cell organelles at the stage of dessicated flower. Control shrubs blooming in May. Six pointed star cytoplasm content released to the intercellular spaces

digestion of the middle pectic layer was evident (Fig. 1b). At the stage of wilted flower, the cell content was further reduced with only a thin cytoplasmic layer (Fig. 1c) with well preserved mitochondria left (Fig. 1c, d) The nuclei were at the similar level of degradation as at the previous stage. The intracellular substance has already been digested (Fig. 1d). At the stage of desiccated flower, the mesophyll cells had no content (Fig. 1e) with only traces of peripheral cytoplasm and degrading mitochondria (Fig. 1f) (data not shown). In the cell walls, clear signs of degradation were visible such as the disappearance of the intercellular substance and the release of cytoplasm into intercellular spaces (Fig. 1g).

PCD in petals of lilacs forced in November

During November forcing, the process of PCD has already been advanced at the stage of the flower bud (Fig. 2a). Most of the observed cells already had condensed peripheral cytoplasm, pressed against the cell wall. In some cells, nuclei with condensed chromatin were present. Inside, chromatin aggregates were localized at the periphery of the nuclei (Fig. 2a). Other organelles still preserved their shape, but they were pushed against the cell wall. In addition, first signs of the intercellular digestion were visible. At the stage of open flower, a lytic vacuole filled nearly the entire cell volume, pushing the cytoplasm remnants with other organelles to the periphery of the cell (Fig. 2b, c). At this stage, the degradation of the intercellular substance was pronounced (Fig. 2d). In some nuclei, their contents were released into the cell volume through broken membranes (not shown). In cells of wilted flowers, the process of PCD was much more advanced than at the same stage in the flowers collected from plants blooming naturally in May. Mesophyll cells were completely filled with a lytic vacuole, and only remnants of cytoplasm were present at the periphery of the cell (Fig. 2e, f). Most of the organelles were completely digested or the digestion process was advanced (Fig. 2e). Degradation was also evident in the cell wall, both in its cellulose and pectin parts (Fig. 2g).
PCD in petals of cut flowers in distilled water: May

At the stage of wilted flowers, a lytic vacuole filled nearly the whole volume of the cell. Organelles, such as nuclei, endoplasmic reticulum or ribosomes appeared digested. Preserved mitochondria, pressed against the cell wall, were present, as well as partly digested plastids with aleuronic grains (Fig. 3a). In places, the intercellular substance between the cell walls was disrupted resulting in separation of the cells and a loss of the tissue structure (Fig. 3a). The outer cell wall was still clearly visible and with no evidence of rupture (Fig. 3b). At the stage of desiccated flower, the mesophyll cells looked similar to these blooming on the shrubs in May. However, in cut flowers, the cellulose cell wall appeared broken in several places, which was not evident in intact flowers.

PCD in petals of cut lilacs in a preservative: May

Observations of Skolimowska et al. (2011) showed that both preservatives tested here were equally effective in prolonging the vase life of cut lilacs 'Mme Florent Stepman'. Observations under the transmission electron microscopy showed no differences in cell senescence between flowers kept in these two preservatives. Therefore, the two treatments were combined into a class "PCD symptoms typical for flowers held in a preservative" and the most representative illustrations for both treatments have been selected.

In petals collected from wilted flowers held in a preservative, the degradation process was slower than in flowers held in water. In the mesophyll cells, the cytoplasm was mostly digested, but still dispersed throughout the volume of the cell, with numerous small vacuoles present (Fig. 3c). In several cells, advanced digestion of nuclei, endoplasmic reticulum and some plastids was observed (Fig. 3c). There was no evidence of the cell wall digestion. At the stage of wilted flower, the cell content was reduced, with only a thin cytoplasmatic layer (Fig. 3d) with well preserved mitochondria and plastids remaining. In some cells, the nuclei could still be observed, but their chromatin was condensed. The cell wall and the intercellular substance were undigested; digestion of the cell wall components started at the stage of the desiccated flower.

\section{PCD in petals of cut lilacs in distilled water: November}

At the stage of wilted flower, a lytic vacuole filled nearly the whole volume of the cell (Fig. 4a). In the peripheral cytoplasm, the organelles such as mitochondria and plastids were present (Fig. 4a). At this stage, the intercellular substance showed advanced signs of degradation what resulted in the separation of cell walls (Fig. 4b). 

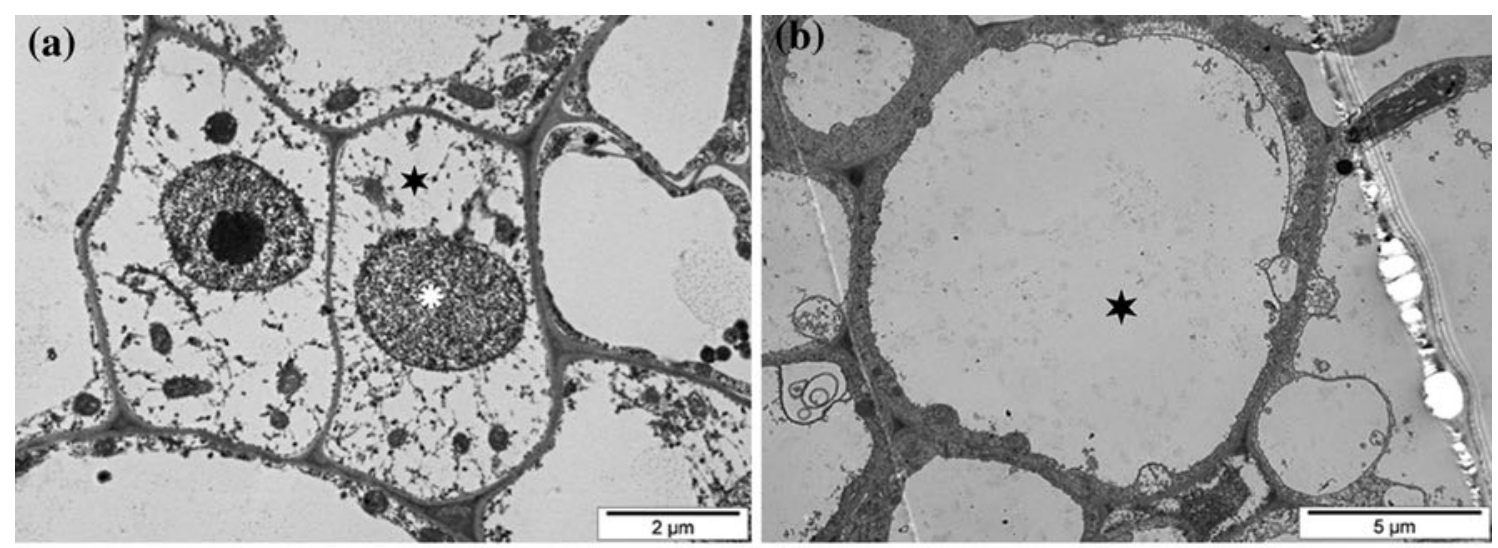

(c)

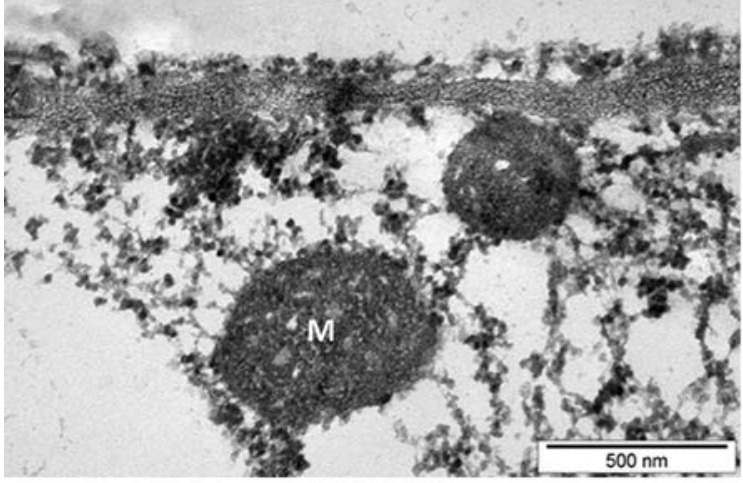

(d)
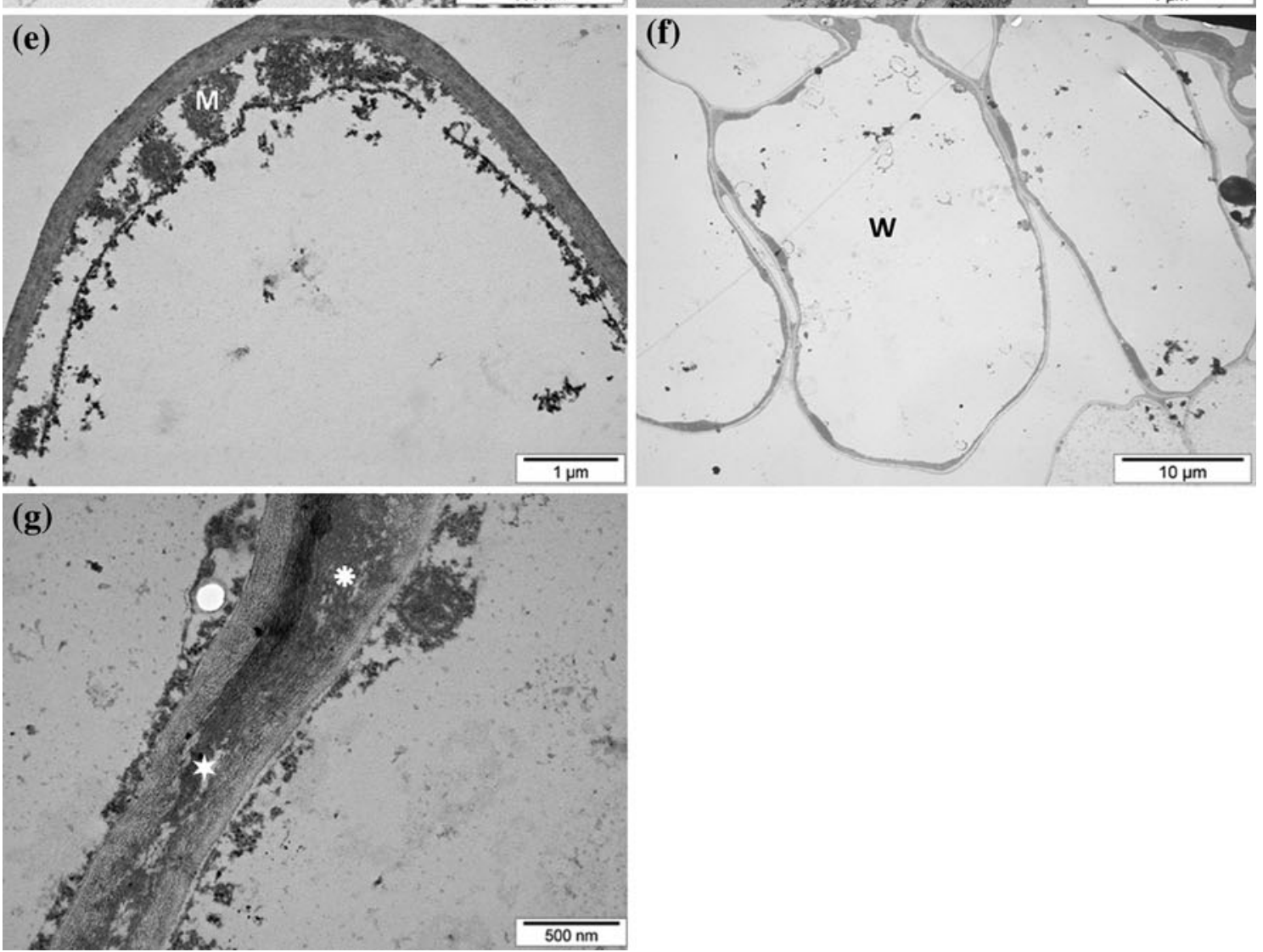
4 Fig. 2 a Degradation of cell organelles at the stage of flower bud. Shrubs forced in November. Six pointed star degrading cytoplasm. Eight pointed star nucleus b. Degradation of cell organelles at the stage of open flower. Shrubs forced in November. Six pointed star vacuole c. Degradation of cell organelles at the stage of open flower. Shrubs forced in November. $M$ mitochondrion d. Degradation of cell organelles at the stage of open flower. Shrubs forced in November. Six pointed star digesting intercellular substance e. Degradation of cell organelles at the stage of wilted flower. Shrubs forced in November. $M$ mitochondrion f. Degradation of cell organelles at the stage of wilted flower. Shrubs forced in November. $W$ vacuole g. Degradation of cell organelles at the stage of wilted flower. Shrubs forced in November. Six pointed star digesting intercellular substance, Eight pointed star degrading cellulose wall

PCD in petals of cut lilacs in a preservative: November

At the stage of wilted flowers, the degradation process was equally advanced in flowers on stems kept in the preservative as those kept in water. Cytoplasm had been pressed against cell walls while some well preserved mitochondria and plastids with lipid droplets were visible (Fig. 4c). The intercellular substance was similarly degraded in flowers from water (Fig. 4c) as from the preservative (Fig. 4d).

\section{Discussion}

Flower senescence is a complex metabolic process strictly controlled by genetic and environmental signals. It manifests itself in different ways in different species, and includes an endogenously controlled process known as PCD. Recently PCD has been studied in the context of the postharvest longevity of cut flowers with the goal of slowing down the processes that ultimately lead to flower death, and to ensure a long display life of cut plant material (Rubinstein 2000; Ichimura et al. 2009). A thorough understanding of the processes that lead to cell death of floral tissues is indispensable to accomplish this goal. Studies on some model plants have shown that the PCD in petals begins during early developmental stages, already in the bud stage (Panavas and Bubinstein 1998; Wagstaff et al. 2003; van Doorn et al. 2003; Battelli et al. 2011; van Doorn and Woltering 2008). Degradation is usually observed at the ultrastructural level, but in such flowers as Alstroemeria (Wagstaff et al. 2003), Iris (van Doorn et al. 2003), Sandersonia (Eason et al. 2002), Hemerocallis
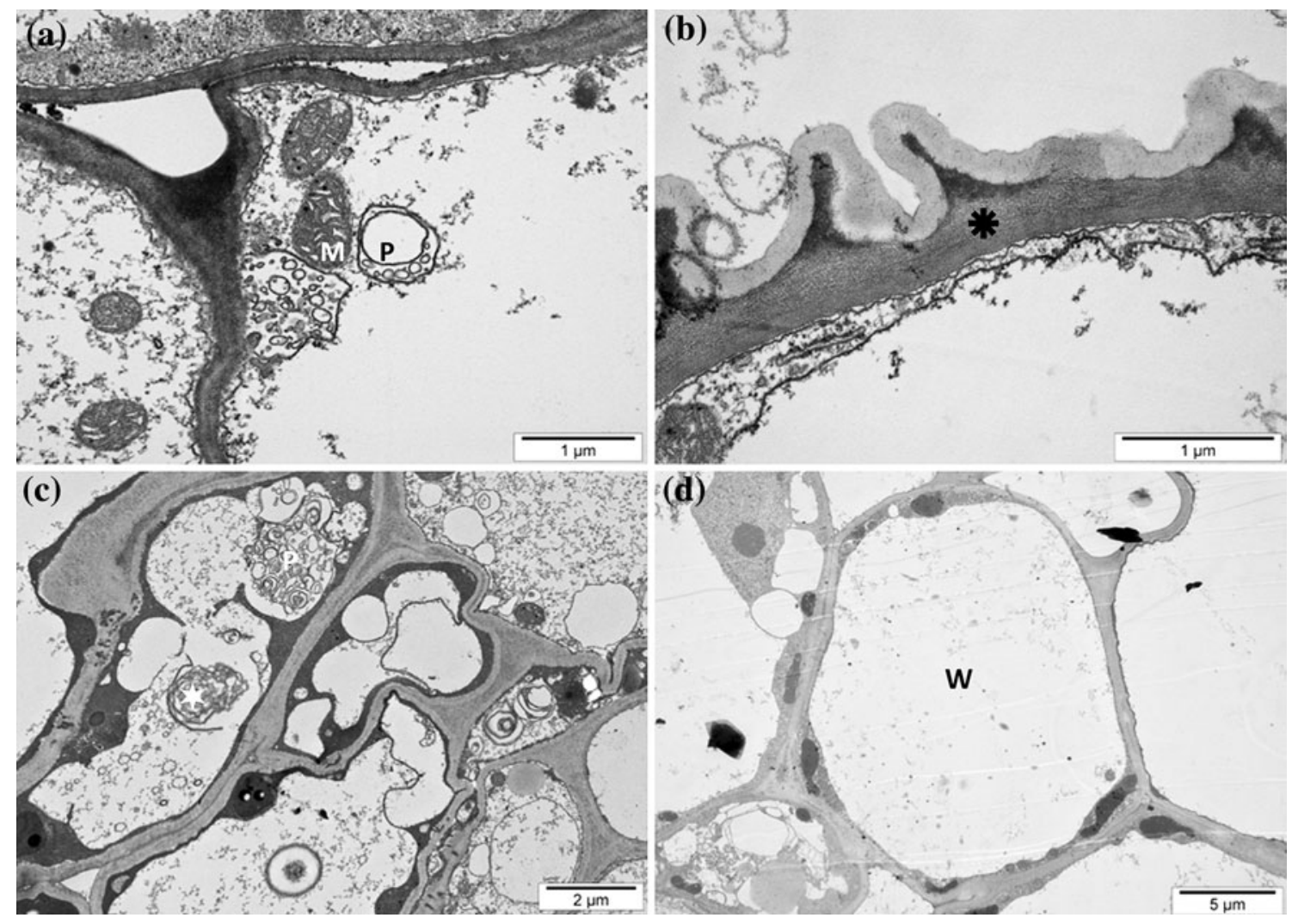

Fig. 3 a Degradation of cell organelles at the stage of wilted flower. Shrubs blooming in May kept in distilled water. $M$ mitochondrion, $p$ degrading plastid $\mathbf{b}$. Degradation of cell organelles at the stage of wilted flower. Shrubs blooming in May kept in distilled water. Eight pointed star cell wall c. Degradation of cell organelles at the stage of

wilted flower. Shrubs blooming in May kept in the preservative. $P$ degrading plastid, Six pointed star degrading ER d. Degradation of cell organelles at the stage of dessicated flower. Shrubs blooming in May kept in the preservative. $W$ vacuole 

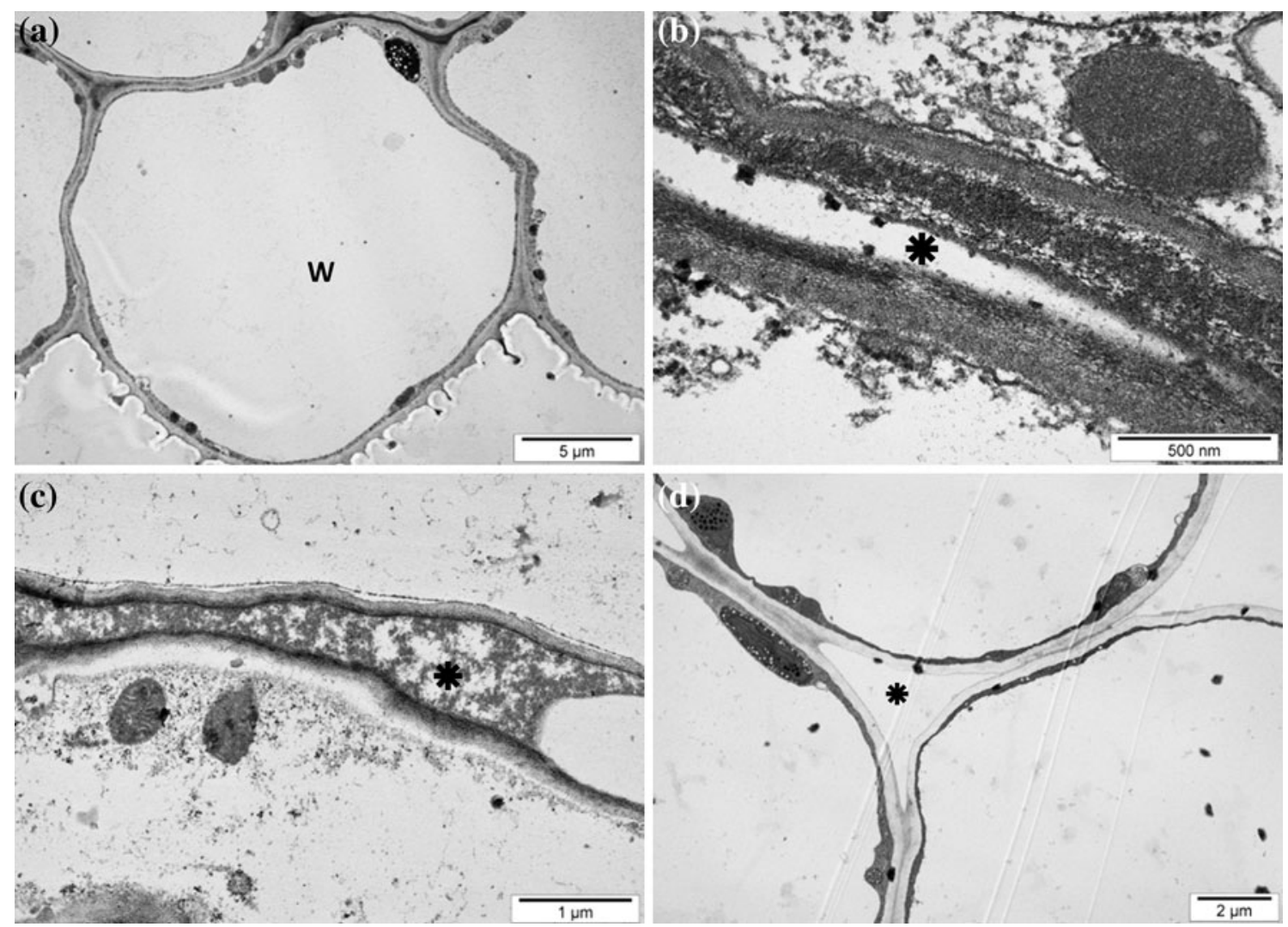

Fig. 4 a Degradation of cell organelles at the stage of wilted flower, shrubs forced in November and kept in distilled water. $W$ vacuole a. Degradation of cell organelles at the stage of wilted flower, shrubs forced in November and kept in distilled water. Eight pointed star degrading intercellular substance c. Degradation of cell organelles at

(Stead and van Doorn 1994), degradation of the mesophyll cells can be observed under the light microscope.

Lilac inflorescences on a shrub can last up 3 weeks, but the longevity of cut branches is greatly reduced (Skolimowska et al. 2011), especially so on flowers produced by forcing. Studies on quality of lilac panicles as affected by the forcing date (Jedrzejuk and Szlachetka 2005; Jędrzejuk 2005; Jędrzejuk and Łukaszewska 2008) showed that the poorest quality of lilac inflorescences was in November when deep shrub dormancy must be overcome by temperatures reaching $35-37{ }^{\circ} \mathrm{C}$. Petals from inflorescences forced in November had much larger intercellular spaces than petals forced in spring or blooming naturally outdoors in May (Jedrzejuk and Łukaszewska 2008). In this study, lilac inflorescences blooming on shrubs forced in November had longevity reduced by 5 days (over $20 \%$ ) relative to lilacs blooming in their natural period in May.

Microscopic examinations of lilac flowers blooming naturally in May showed the first symptoms of the PCD already at the stage of flower bud, and they were advanced by the stage of open flower. The first symptoms of nucleus degradation were observed in lilacs at the stage

the stage of wilted flower. Shrubs forced in November kept in the preservative. Eight pointed star degrading intercellular substance d. Degradation of cell organelles at the stage of dessicated flower. Shrubs forced in November kept in the preservative. Eight pointed star digested intercellular substance

of flower bud. According to Wagstaff et al. (2003) nucleus is the organelle that begins to degrade at a very early stage of petal development. Although nuclei in the lilac petal cells start to degrade so early, its complete degradation was not clearly evident until the stage of the desiccated flower. The ultrastructural changes observed in nuclei were similar to those described earlier for different plant species. In tobacco petals, the nuclei show nuclear blebbing, similar to that observed during apoptosis in animal cells (Serafini-Fracassini et al. 2002). In young cells, chromatin is quite evenly distributed in the nuclei. During cell senescence, chromatin clumps into different density patches that may be distributed either throughout the entire nucleus, or concentrate at the nuclear periphery. In several species, nuclei show brighter fluorescence after staining with a fluoro probe for DNA, showing DNA condensation. Chromatin redistribution is often accompanied by a decrease in nuclear diameter (Yamada et al. 2007a, b).

Mitochondria are considered the most stable cell organelles. In petals of common lilac, their degradation was observed only at the stage of desiccated flower. 


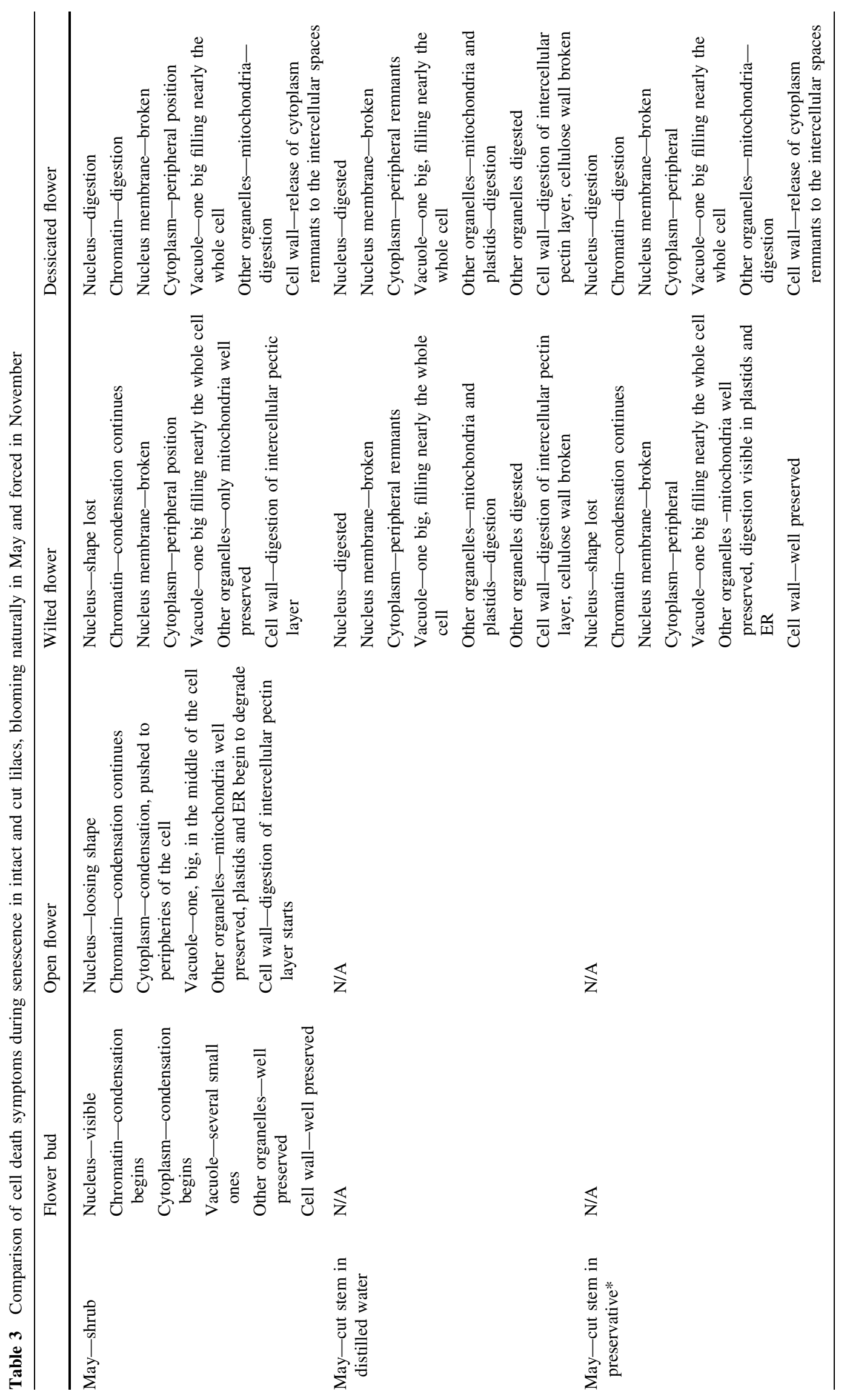




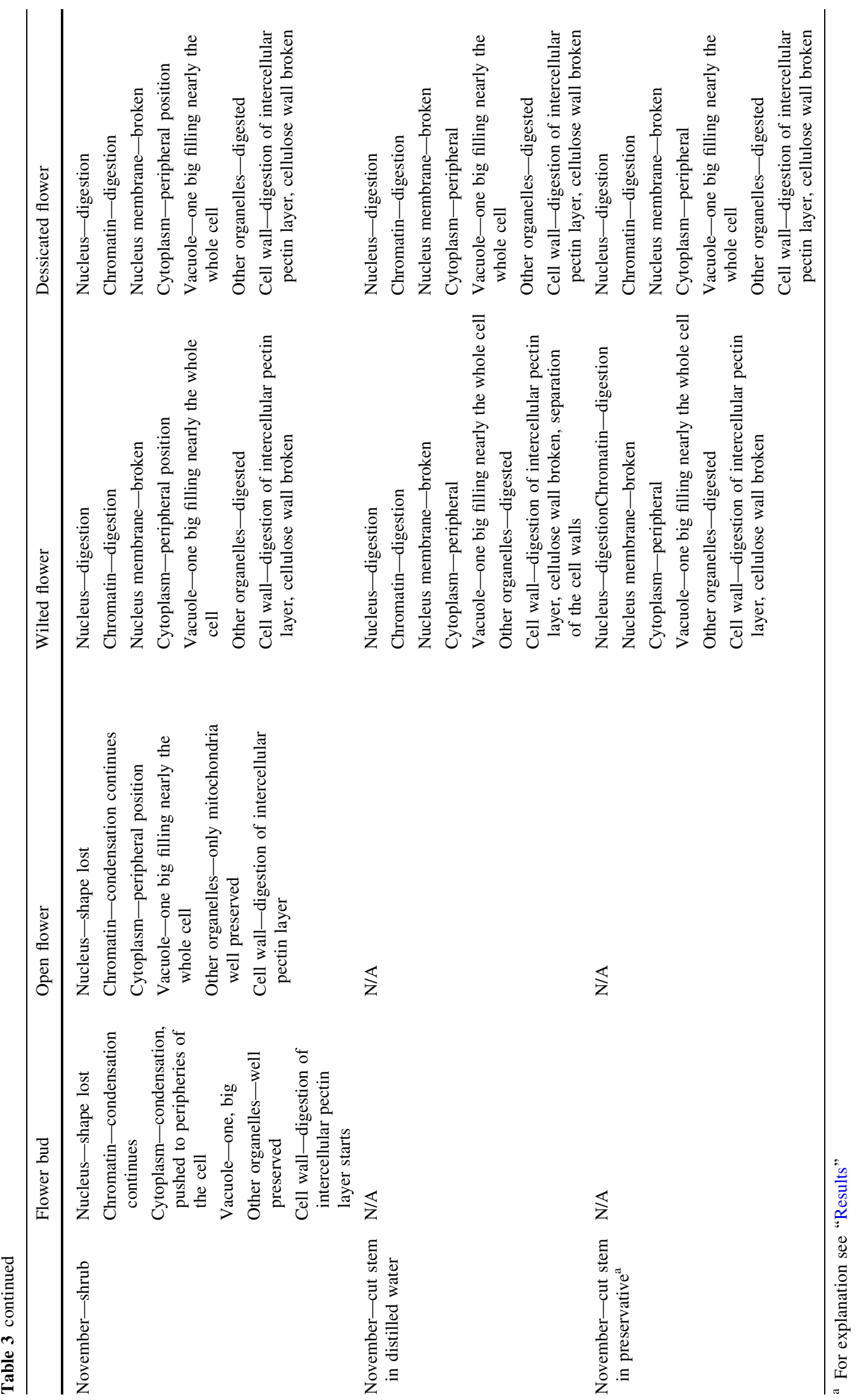


Petal cells in Ipomoea (Winkenbach 1970), carnation (Smith et al. 1992), Hemerocallis (Stead and van Doorn 1994), and Iris (van Doorn et al. 2003) show a reduction in the number of small vacuoles, and an increase in the vacuolar size. The ongoing increase in the vacuole volume in Iris was accompanied by the loss of a considerable part of the cytoplasm, and with the disappearance of most organelles. A similar pattern of the vacuole volume increase was observed here in common lilac, where eventually, the cytoplasm remained only as a thin layer at the cell periphery, pressed against the cell wall.

At the stage of desiccated flower, the cellulose cell wall was broken in several places in cells from flowers cut in May. No such changes were detected in the petals from the same stage sampled from shrubs growing outdoors. Under forcing, in November, this degradation was considerably faster than in May, showing clear signs of cell wall degradation already at the stage of the wilted flower.

Generally, in petals from forced shrubs the first symptoms of cell degradation were evident at the stage of the flower bud, and they were much more advanced than in lilacs blooming naturally in May (Table 3). In this sense, forcing clearly accelerates the onset of PCD.

Senescence causes decrease in mesophyll cells size in the petals of many senescing plants (van Doorn and Woltering 2008, Shahri and Tahir 2011, Xu et al. 2006, Panavas and Bubinstein 1998). In common lilac we could confirm this fact. We proved as well that forcing lilacs to bloom also decreases the size of mesophyll cells in the petals.

The preservatives used commercially to prolong cut flower longevity delayed the degradation of cell organelles in the petals of lilacs flowering in May but not in November. Earlier observations of Jędrzejuk and Zakrzewski (2009) showed that both preservatives also limited tylose formation in lilac stems thus permitting unimpeded water transport to the inflorescences and prolonging the vase life. This double effect of the preservatives may reflect the role that positive water balance plays in maintaining lilac inflorescence longevity: uninterrupted water uptake and transport postpones the threat of premature flower senescence. It is interesting that the positive water balance in cut lilacs can be maintained by two solutions that differ substantially in their composition and their mode of application. Chrysal Professional 2 contains a potent but unknown biocide that is likely responsible for the effect on the water balance of flowers while in the standard preservative, a "flower food', sucrose seems to play a substantial role in delaying senescence The postharvest longevity of flowers is also related to the endogenous sugar content which drops in senescing cut flowers as they usually do not assimilate after harvest, but survive on their reserves or on exogenous sugars supplied in flower preservatives (Mayak and Halevy 1980; Ichimura et al. 2009; Arrom and Munne-Bosch 2012). In addition, in cut lilacs, the contents of soluble sugars decrease during the vase life and when held in a preservative containing sugar, they do accumulate sugars in flower petals (Skolimowska et al. 2011) and such an accumulation does not occur in lilacs held in the solution of Chrysal Professional 2 as it is not a real "flower food" and its aim is only to support flower life during the market chain by assuring uninterrupted water uptake. Exogenous sugar prolongs the flower vase life as it serves as an energy source, and it increases the cell osmoticum, and acts as a driving force for the water influx and flower opening (Mayak and Halevy 1980). It has a role in regulating the gene expression and hormonal balance in flowers (Eason 2006; Arrom and Munne-Bosch 2012). This last aspect needs detailed studies in forced lilacs. High forcing temperatures probably affect a hormonal balance in lilac flowers, as can be deduced from the degenerative changes taking place in the generative structures of flowers from the early forcing dates (Jędrzejuk 2005; Jędrzejuk and Łukaszewska 2008) and such hormonal changes due to forcing procedures possibly hasten flower senescence after harvest. The successive studies on lilac flower senescence should include analyses of endogenous hormones, combined with a closer control of the thermal conditions during the forcing procedure.

Authors' contribution Agata Jędrzejuk designed and carried out the experiments provided the preparation of the study material, analysed the results, and wrote the manuscript. Julia Rochala conceived of research area. Marta Dolegasupervised statistical analyses. Aleksandra Łukaszewska contributed scientific advice, correction, and final revision of the manuscript.

Acknowledgments Experiments were carried out within the frames of the MNiSW project NN310 089336.

Open Access This article is distributed under the terms of the Creative Commons Attribution License which permits any use, distribution, and reproduction in any medium, provided the original author(s) and the source are credited.

\section{References}

Arrom L, Munne-Bosch S (2012) Sucrose accelerates flower opening and delays senescence through hormonal effect in cut lily flowers. Plant Sci 188-189:41-47

Battelli R, Lombardi L, Rogers HJ, Picciarelli P, Lorenzi R, Ceccarelli N (2011) Changes in ultrastructure, protease, caspase-like activities during flower senescence in Lillium longiflorum. Plant Sci 180(5):716-725

Borkowska B (1987) Aspekty fizjologiczne rozwoju pąków u roślin drzewiastych (Physiological aspects in bud development in trees). Wiadomości Botaniczne 31:227-236 
Dale A, Sample A, King E (1999) Breaking dormancy in red raspberries for greenhouse production. Hortic Sci 38(4):515-519

Eason JR (2006) Molecular and genetic aspects of flower senescence. Stewart Postharvest Rev 2:1-7

Eason JR, Ryan DJ, Pinkney TT, O’Donoghue EM (2002) Programmed cell death during flower senescence: isolation and characteristics of cysteine proteinases from Sandersonia aurantiaca. Funct Plant Biol 29:1055-1064

Ellis RE, YuanJ Horvitz HR (1991) Mechanisms and functions of cell-death. Ann Rev Cell Biol 7:663-698

Green DR (1998) Apoptotic pathways: the roads to ruin. Cell 94:695-698

Greenberg JT (1996) Programmed cell death: a way of life for plants. Proc Natl Acad Sci USA 93:12094-12097

Ichimura K, Yamada T, Shimizu-Yumoto H (2009) Recent breakthroughs in postharvest physiology research and cut flower handling in Japan. Hort Environ Biotechnol 50(6):539-545

Jędrzejuk A (2005) Ultrastructure of pollen grains from forced and unforced shrubs in common lilac. J Plant Growth Regul 24:1-10

Jędrzejuk A, Łukaszewska A (2008) High temperatures applied at fall forcing disturb ovule development in Syringa vulgaris L. "Mme Florent Stepman". Acta Physiol Plant 30:673-678

Jędrzejuk A, Szlachetka W (2005) Development of flower organs in common lilac. Acta Biologica Cracoviensia 47(2):41-52

Jędrzejuk A, Zakrzewski J (2009) Xylem occlusions in the stems of common lilac during postharvest life. Acta Physiologiae Plantarum 31(6): 1147-1153

Matile P, Winkenbach F (1971) Function of lysosomes and lysosomal enzymes in the senescing corolla of the morning glory (Ipomoea purpurea). J Exp Bot 22:759-771

Mayak S, Halevy AH (1980) Interrelationships of ethylene and abscisic acid in the control of rose petal senescence. Plant Physiol 50:341-346

Mittler R, Shulaev V, Seskar M, Lam E (1996) Inhibition of programmed cell death in tobacco plants during pathogen induced hypersensitive response at low oxygen pressure. Plant Cell 8:1991-2001

Molenar P (2009) Walka ze stratami czyli produkty firmy Chrysal, a posprzętna jakość ciętych kwiatów. In: Łukaszewska A. (ed) Niech żyją kwiaty w wazonie. SGGW w Warszawie. pp 185-197

Panavas T, Bubinstein B (1998) Oxidative events during programmed cell death of daylily (Hemerocallis hybrida) petals. Plant Sci 133:125-138

Pennell RI, Lamb C (1997) Programmed cell death in plants. Plant Cell 9:1157-1168

Phillips HL, Kende H (1980) Structural changes in flowers of Ipomoea tricolor during flower opening and closing. Protoplasma 102:199-215

Rabiza-Swider J, Skutnik E (2010) Wskaźniki starzenia w ocenie pozbiorczej trwałości u lilaka pospolitego (Syringa vulgaris L.). Zesz Probl Post Nauk Rol 551: 313-320

Robinson DG, Ehlers U, Herken R, Herrmann B, Mayer F, Schuermann FW (1987) Methods of Preparation for Electron Microscopy. An introduction for the Biomedical Sciences, Springer-Verlag

Rubinstein B (2000) Regulation of cell death in flower petals. Plant Mol Biol 44:303-318
Serafini-Fracassini D, Del Duca S, Monti F, Poli F, Sacchetti G, Bregoli AM, Biondi S, Della Mea M (2002) Transglutaminase activity during senescence and programmed cell death in the corolla of tobacco (Nicotiana tabacum) flowers. Cell Death Differ 9:309-321

Shahri W, Tahir I (2011) Flower development and senescence in Ranunculus asiaticus L. J Fruit Ornam Plant Res 19(2):123-131

Skolimowska K, Łukaszewska A, Adamczyk D, Rochala J (2011) Postharvest performance of forced cut lilacs 'Mme Florent Stepman' as affected by harvest date and preservatives. Ann Warsaw Uni Life Sci-SGGW. Horticult Landsc Architect 32:43-51

Smith MT, Saks Y, van Staden J (1992) Ultrastructural changes in the petals of senescing flowers of Dianthus caryophyllus L. Ann Bot 69:277-285

Stead AD, van Doorn WG (1994) Strategies of flower senescence a review. In: Scott RJ, Stead AD (eds) Molecular and cellular aspects of plant reproduction. Cambridge University Press, Cambridge, pp 215-238

Sytsema-Kalkman EC (1991) Post-harvest studies on Syringa vulgaris. Acta Hort 298:127-134

van Doorn WG, Woltering EJ (2008) Physiology and molecular biology of petal senescence. J Exp Bot 59(3):453-480

van Doorn WG, Balk PA, van Houwelingen AM, Hoeberichts FA, Hall RD, Vorst O, van der Schoot C, van Wordragen MF (2003) Gene expression during anthesis and senescence in Iris flowers. Plant Mol Biol 53:845-863

Vaux DL, Korsmeyer SJ (1999) Cell death in development. Cell 96:245-254

Wagstaff C, Malcolm P, Rafiq A, Leverentz M, Griffiths G, Thomas B, Staed A, Rogers H (2003) Programmed cell death (PCD) processes begin extremely early in Alstroemeria petal senescence. New Phytol 160:49-59

Wareing I (1985) Wzrost i różnicowanie roślin (growth and differentiation of plants). PWN Warszawa

Wertz IE, Hanley MR (1996) Diverse molecular provocation of programmed cell death. Trends Biochem Sci 21:359-364

White E (1996) Life, death, and the pursuit of apoptosis. Genes Dev 10:1-15

Winkenbach F (1970) Zum Stoffwechsel der aufblühenden und welkenden Korolle der Prunkwinde Ipomoea purpurea. II. Funktion und de novo Synthese lysosomaler Enzyme beim Welken. Berichte der schweizerischen botanischen Gesellschaft 80:391-406

Xu Y, Ishida H, Reisen D, Hanson MR (2006) Upregulation of a tonoplast-localized cytochrome $\mathrm{P} 450$ during petal senescence in Petunia inflata. BMC Plant Biol. doi:10.1186/1471-2229-6-8

Yamada T, Ichimura K, Kanekatsu M, van Doorn WG (2007a) Gene expression in opening and senescing petals of morning glory (Ipomoea nil) flowers. Plant Cell Rep 26:823-835

Yamada T, Ichimura K, van Doorn WG (2007b) Relationship between petal abscission and programmed cell death in Prunus yedoensis and Delphinium belladonna. Planta 226:1195-1205 